\title{
Potential Management Alternatives for Invaded Rangelands in the Northern Great Plains
}

\section{By Shawn DeKeyser, Miranda Meehan, Kevin Sedivec, and Chuck Lura}

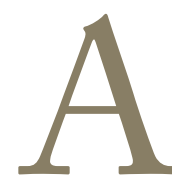

concern for many rangeland managers in the Northern Great Plains is how to control or profitably utilize exotic invasive plant species. Large percentages of the Northern Great Plains rangelands are currently dominated by exotic invasive species, and arguably certain ecoregions have crossed a threshold where the natural plant communities have been forever transformed to contain these species as major components. The mechanisms of invasion by these species are often weakly understood, if researched at all, which only confounds what proper management should be. If these species invasions have caused irreversible changes, then it may be time for land managers to adapt strategies to better utilize the current resources available in an ecologically sound way, and not focus management toward an unattainable presettlement state of vegetation.

\section{Management and Vegetation}

Management of vegetation of the Northern Great Plains has often focused on the directing succession toward presettlement native plant assemblages or the "historic climax plant community." Even though sound management has prevailed on many Northern Great Plains rangelands, spread of exotic species has not slowed in many cases. Currently more than $17 \%$ of the total number of plant species in the Northern Great Plains is introduced, ${ }^{1}$ and large expanses of rangeland are dominated by invasive introduced species. Adding to this effect of invasive species is the dwindling amount of native rangeland remaining. Only about $2 \%$ of the northern tallgrass prairie remains today, with the remaining mixed grass prairie making up only $25 \%-31 \%{ }^{2}$ The eastern extent of the Northern Great Plains has the least amount of rangeland remaining, with the northwestern extent having moderate amounts remaining, and the southwestern extent having the most native rangeland remaining. Increased, and ongoing, habitat fragmentation has to some degree increased the opportunity for invasion by introducing species such as smooth bromegrass (Bromus inermis Leyss.) and crested wheatgrass (Agropyron cristatum [L.] Gaertn., Agropyron desertorum [Fisch. ex Link] Schult.), which were used to stabilize erodible soils of previously cultivated marginal lands. Other intentional introductions of invasive species include sweetclover (Melilotus officinalis [L.] Lam.) as a forage species and Kentucky bluegrass (Poa pratensis L.) as a forage and turf grass.

\section{Species and the Extent of Spread}

The majority of rangelands found in the Northern and Northwestern Glaciated Plains ecoregions and far eastern portions of the Northwestern Great Plains ${ }^{3}$ (Fig. 1) presently have the two introduced cool-season species, smooth bromegrass and Kentucky bluegrass, as dominant species of the major ecological sites. ${ }^{4,5}$ These species are highly competitive perennial grasses that initiate early spring growth before the emergence of native species endemic to the region. Being bred as a turf grass Kentucky bluegrass has a strong ability to tiller and form dense root mats; it can survive under varying levels of heat and drought stress ${ }^{6}$ and is bred to germinate readily. The numerous rhizomes produced by smooth bromegrass give it a competitive advantage over many native species. ${ }^{7}$ Although Kentucky bluegrass has the ability to be competitive on many different ecological sites, smooth bromegrass is better suited for loamy ecological sites. One concern of the spread of these species is the potential to occupy sites once inhabited by warmseason grasses, as has been noted in other Great Plains regions. ${ }^{8}$ This potential loss in seasonality of Northern Great Plains grasslands could mean an overall loss of ecosystem 


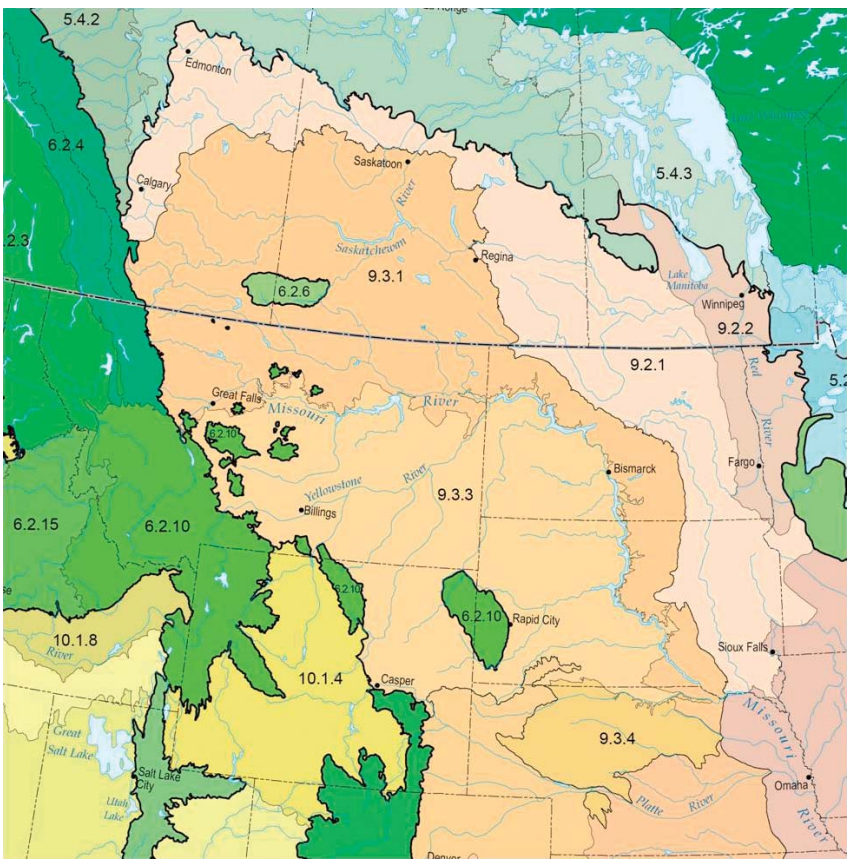

Figure 1. Level III Ecoregions of the Northern Great Plains (printed with permission by the Commission for Environmental Cooperation). ${ }^{3}$ Here 9.2.1 indicates Aspen Parkland/Northern Glaciated Plains; 9.2.2, Lake Manitoba and Lake Agassiz Plains; 9.3.1, Northwestern Glaciated Plains; 9.3.3, Northwestern Great Plains; 9.3.4, Nebraska Sand Hills; 6.2.6, Cypress Upland; and 6.2.10, Middle Rockies.

functioning (e.g., annual nutrient cycling, hydrologic cycling, and energy flow). In places where these species do spread, there has been a significant decrease in the cover and frequency of native graminoid and forb species. ${ }^{4,5}$

Similarly, cool-season perennial crested wheatgrass has been introduced into the western and northern portions of the Northern Great Plains to revegetate marginal croplands. Crested wheatgrass is a persistent invader in the west because

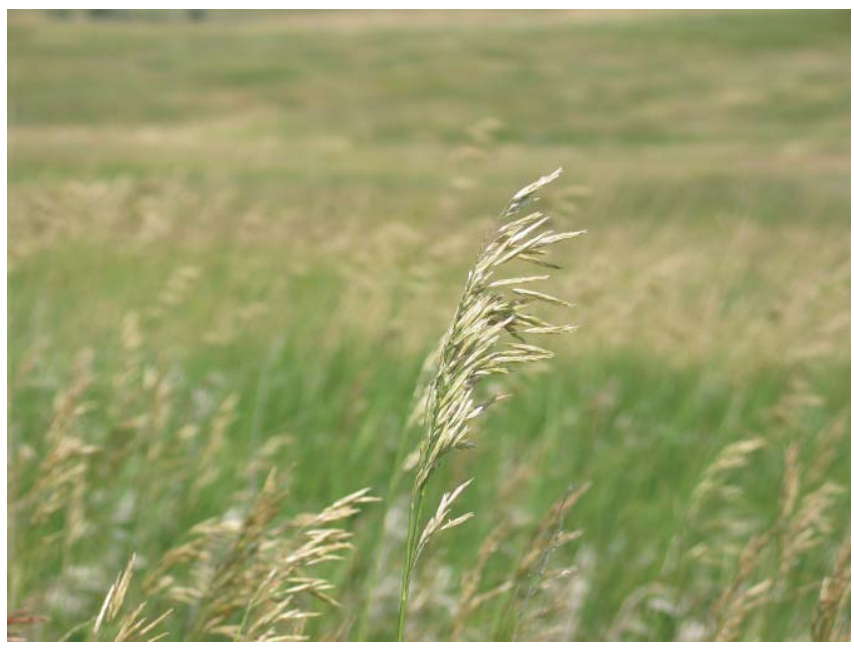

Smooth bromegrass is now a dominant component of many rangelands in the Northern Great Plains. Photo by Shawn DeKeyser.

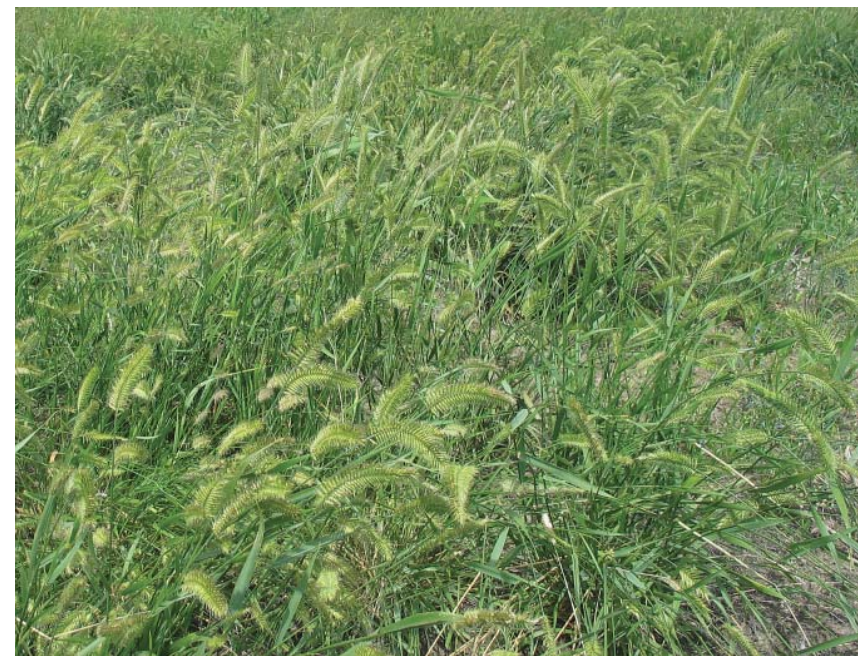

Crested wheatgrass is especially invasive in the western portions of the Northern Great Plains. Photo by Shawn DeKeyser.

of its ability to withstand heavy grazing, capability for surviving cold and drought stress, high productivity, capacity to compete, and ability to produce a large number of viable seeds. ${ }^{9}$ In fact, it is such a strong competitor that it has been planted in the western United States to prevent the establishment of other invasive species such as knapweeds (Centaurea spp.) and cheatgrass (Bromus tectorum L.). ${ }^{10}$ Once crested wheatgrass is introduced, it persists as the dominant species for prolonged periods and decreases below-ground carbon and nitrogen cycling. ${ }^{11}$ Overall, the effect of its presence is a decrease in the diversity and composition of native prairie communities. ${ }^{12}$

Both cheatgrass and Japanese brome, also known as field brome (Bromus arvensis L.), have been noted as invasive species of grasslands and agricultural areas within the western United States including the Northern Great Plains, invading millions of hectares nationwide for over 80 years. ${ }^{13,14}$ The impact of annual bromes on ecological communities such as sagebrush steppe is common knowledge, transforming once diverse communities into monocultural stands of annual bromegrasses. ${ }^{15}$ In the Northern Great Plains, annual bromes have been shown to decrease the above- and belowground seasonal biomass within rangeland communities; ${ }^{16}$ however, their removal has been shown to increase native graminoid production over time. ${ }^{17}$

Broadleaf noxious weeds such as leafy spurge (Euphorbia esula L.) have also changed the ecological processes of rangeland today. Leafy spurge is considered one of the most serious noxious weeds in the northern and central plains, ${ }^{18,19}$ with substantial negative economic impacts estimated at close to $\$ 130$ million annually in North Dakota, South Dakota, Montana, and Wyoming. ${ }^{20}$ It should be pointed out that a large percentage of this loss was estimated as loss of forage, thus production, for beef cattle. Once leafy spurge invades rangelands of the Northern Great Plains, native 


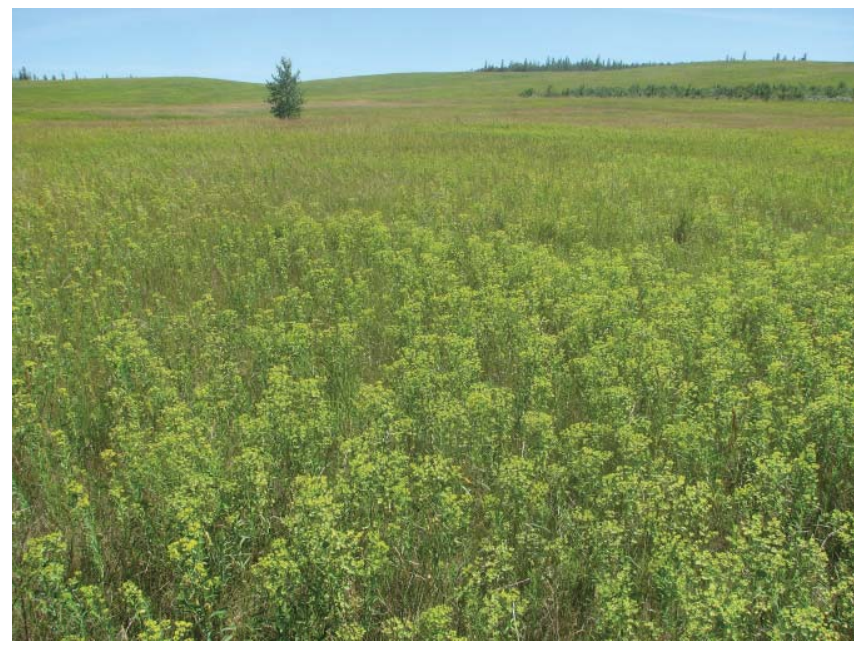

Leafy spurge has invaded rangelands throughout the Northern Great Plains. Photo by Dennis Whitted.

plant species become displaced, and exotic grasses such as Kentucky bluegrass and smooth bromegrass often invade, creating a plant community that functions quite differently from the diverse, historic native plant community. ${ }^{21}$

Three species of knapweeds are of increasing concern in the Northern Great Plains. Spotted knapweed (Centaurea stoebe L.), diffuse knapweed (Centaurea diffusa Lam.), and Russian knapweed (Acroptilon repens [L.] DC.) are classified as noxious weeds in North Dakota, Montana, and Manitoba. By 2000 these three species were estimated to infest over 1.2 million hectares in North Dakota and Montana. ${ }^{22}$ More recently Sheley et al. ${ }^{23}$ noted that spotted knapweed has spread to occupy over two million hectares in Montana. If knapweed continues to spread at present rates, it is expected to dominate most western rangelands in a hundred years. ${ }^{24}$ Similar to other invasive exotics, the knapweeds can alter the botanical composition of range plant communities. Tyser and $\mathrm{Key}^{24}$ found that spotted knapweed can invade and alter the composition of fescue grasslands in Glacier National Park, where increases in spotted knapweed density were inversely related to species richness. Knapweed invasions can also lead to increased soil erosion and reduce forage production, subsequently reducing the grazing capacity of rangelands as well as wildlife diversity and production..$^{25}$

Several other notable invasive species occupy thousands of hectares in the Northern Great Plains that are either widespread or habitat specific (e.g., riparian invasion). A few other common graminoid invaders include quackgrass (Elymus repens [L.] Gould), johnsongrass (Sorghum halepense [L.] Pers.), and reed canarygrass (Phalaris arundinacea L.). Other broadleaf invaders include Canada thistle (Cirsium arvense [L.] Scop.), absinth wormwood (Artemisia absinthium L.), yellow and Dalmatian toadflax (Linaria vulgaris Mill. and Linaria dalmatica [L.] Mill), sweetclover, and purple loosestrife (Lythrum salicaria L.). Although the

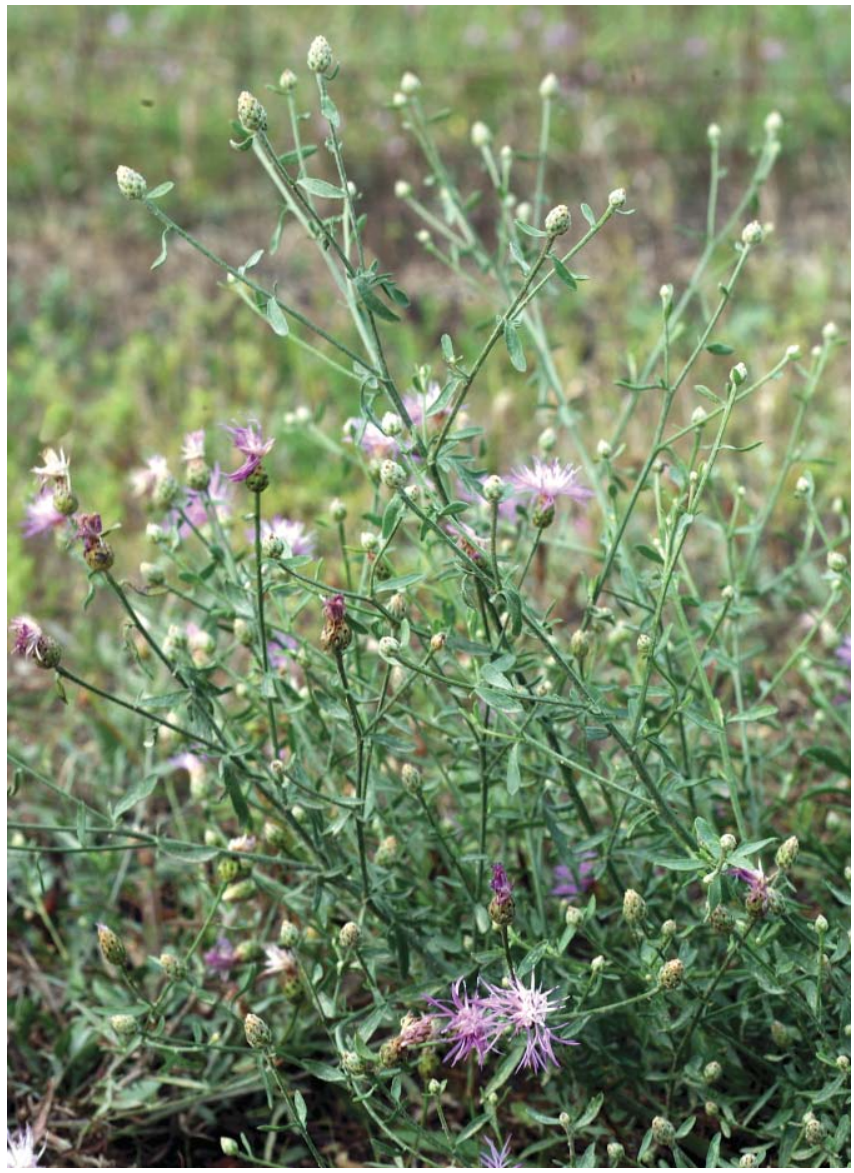

Knapweeds dominate large expanses of rangeland in the western Northern Great Plains. Photo by Rod Lym.

Northern Great Plains has fewer introduced woody invaders, both saltcedar (Tamarix spp.) and Russian olive (Eleagnus angustifolia L.) are becoming increasing concerns, especially within riparian communities. Finally, nonindigenous cattails (Typha angustifolia L., Typha $\times$ glauca Godr.) are common invaders of wetlands throughout the Prairie Pothole Region and other regions of the Northern Great Plains.

\section{Are Alternative Management Considerations Needed?}

Needless to say, invasive species have greatly influenced the current vegetation and soil properties and dynamics within the Northern Great Plains. In many cases, if not most, it is more difficult to locate rangelands not impacted by invasive species than rangelands that are impacted. This is especially true in the eastern Northern Great Plains, where it could be argued, there are no rangelands remaining that are not impacted by invasive species. Much is known about the history and expansion for several of these invasive species; however, proper management of rangelands with these species is still unknown. For example, traditional range management starting dates of approximately late May to early June (3.5 leaf stage of native grasses) in central North Dakota may give Kentucky bluegrass and smooth 
bromegrass a competitive advantage because of their earlier spring initiation of growth. Another example is that much of our livestock production from Northern Great Plains rangelands is geared toward one species (cattle or sheep), which gives plant species not selected and eaten by livestock a competitive advantage (e.g., leafy spurge not being eaten by cattle). Other than federal agencies, such as the US Forest Service and US Fish and Wildlife Service, little use is made of fire as a potential management tool by rangeland managers in the Northern Great Plains.

Other present and past management practices, overgrazing or no grazing, ${ }^{5}$ have both been noted to facilitate the invasion of smooth bromegrass and Kentucky bluegrass. Thus it would appear that a change in current management practices is required to combat their invasion. The main management tools that appear to have promise for decreasing the dominance of these two species in the Northern Great Plains are fire and managed grazing. The interactions of these disturbances have been shown to play an important role in ecosystem function in other areas of the Great Plains, ${ }^{26}$ making them important habitat management factors for maintaining the integrity of ecosystems. A change in current grazing management can decrease the competitive advantage of cool-season grasses. ${ }^{27-29}$ Intensive grazing effectively controls smooth bromegrass, ${ }^{27}$ and intensive early-season grazing reduces the cover of Kentucky bluegrass. ${ }^{28}$ The reintroduction of fire to tallgrass prairie ecosystems is associated with significant increases in biomass production of native warm-season grasses ${ }^{30}$ because of elevated levels of bud densities. ${ }^{31}$ Late spring and summer burning have been documented as increasing the frequency of warm-season grasses, ${ }^{32,33}$ and spring burning reduces the frequency of Kentucky bluegrass. ${ }^{32}$ Anderson and McMurphy ${ }^{33}$ stated that burning in any season reduced the vigor of Kentucky bluegrass over nonburned tallgrass prairie ecosystems. In the Northern Great Plains, spring burning in conjunction with intensive early spring grazing significantly reduced cool-season grasses, allowing for an increase in warm-season grasses. ${ }^{29}$ Similar trends were found for areas that were rotationally grazed following a spring prescribed burn in the Northern Great Plains. ${ }^{28}$ Managing invasive cool-season grasses using a combination of burning and grazing increases plant species diversity in tallgrass prairie ecosystems over burning alone. ${ }^{34}$ The best option for utilizing invasive cool-season grasses while promoting overall diversity is through the manipulation of naturally occurring disturbances, specifically grazing and fire management.

Research controlling the spread and potential eradication of leafy spurge has been conducted since the 1930s. Herbicides have been the most popular tool for control of leafy spurge; however, they are often expensive and not cost effective. ${ }^{35}$ Biological control of leafy spurge with insects has been suggested to be the most cost-effective and likely best long-term control method. ${ }^{36}$ However, leafy spurge has been shown to be a nutritious forage species, ${ }^{37}$ and grazing with

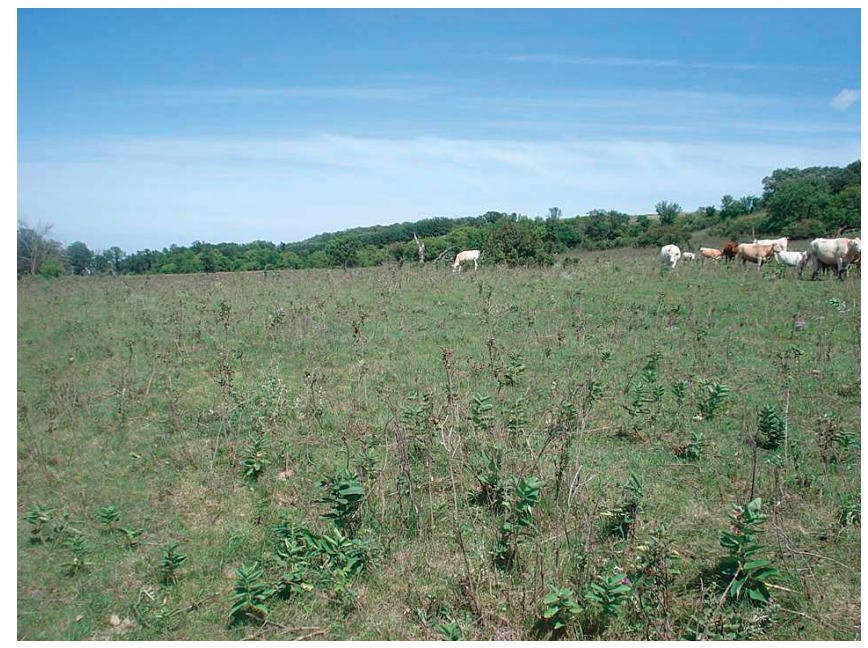

Overgrazing promotes Kentucky bluegrass in the Northern Great Plains along with several other invasive species. Photo by Miranda Meehan.

goats and sheep can provide an economic return while controlling its spread. $^{38}$ It should be pointed out that although biological control techniques have created a decline in the overall population of leafy spurge in the Northern Great Plains, ${ }^{20,39}$ the resulting plant community without leafy spurge remains dominated by exotic plant species and is low in native plant diversity. ${ }^{22}$ This change has created a rangeland resource much different from rangelands of the presettlement era. Describing the plant communities of the northern plains will include the native plants, with exotic, invasive plants an integral part of the community.

Numerous examples exist nationwide where invasive species are being utilized by livestock such as cattle, sheep, goats, as well as other alternative livestock. Sheep and goats are currently utilizing knapweeds, tansy ragwort (Senecio jacobaea L.), Canada thistle, yellow star thistle (Centaurea

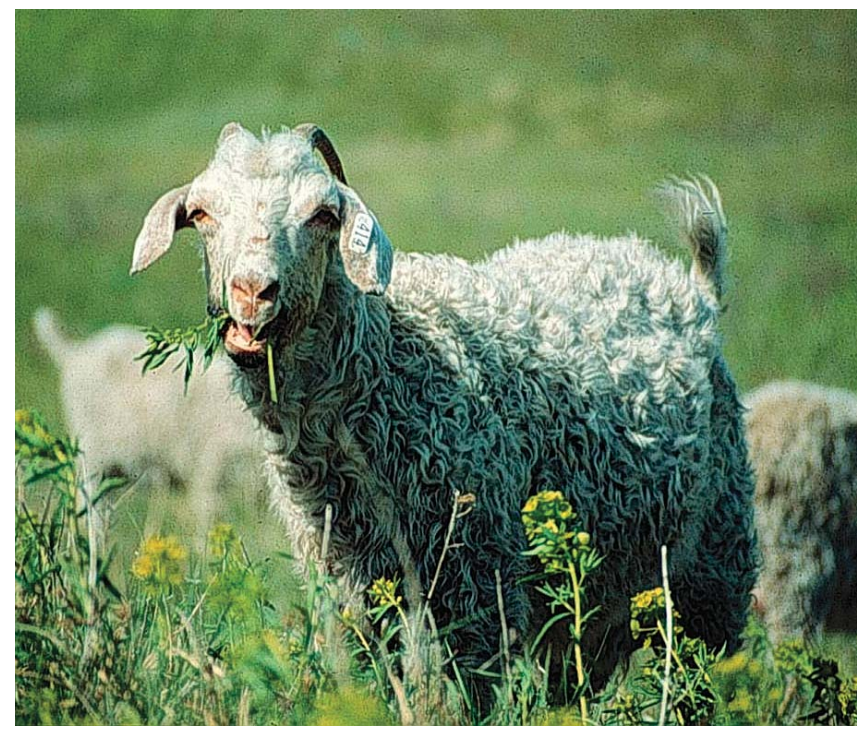

Both goats and sheep will readily utilize leafy spurge, which is as nutritious as alfalfa. Photo by Don Kirby. 


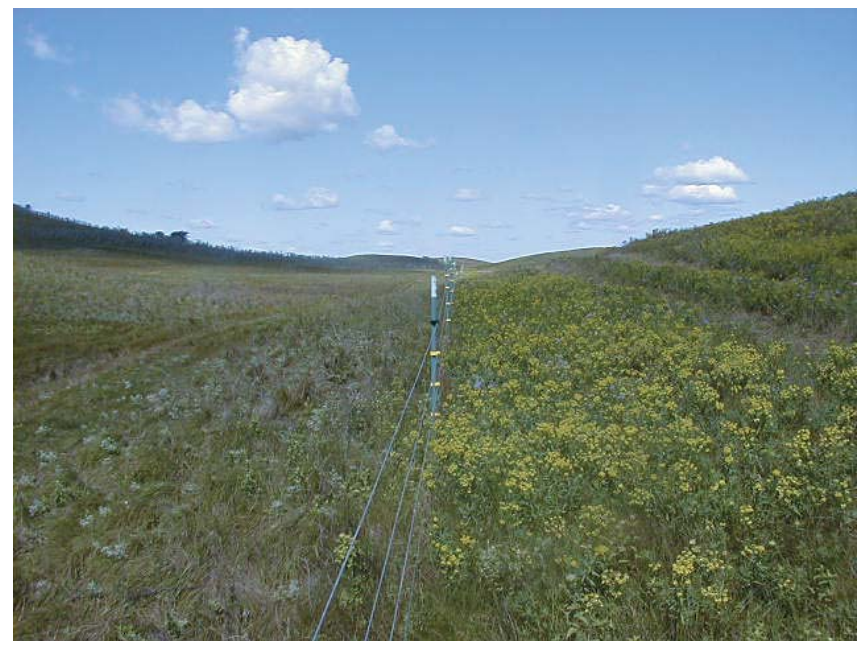

Fence line contrast of multispecies grazing impacts on leafy spurge and prairie health with cattle and sheep (left) and cattle only (right). Photo by Dennis Whitted.

solstitialis L.), woody invaders, and many others, which can include some poisonous plants. Cattle are utilizing cheatgrass, Canada thistle, musk thistle (Carduus nutans L.), as well as other forages usually not preferred within their diet. Finally, other breeds and classes of meat-producing livestock are currently foraging on invasive species worldwide that have not been considered in the United States yet.

\section{Conclusion}

One of the first principles learned in rangeland management is to adapt livestock operations to the type of rangeland being managed, which is primarily dependent on the type of vegetation comprising that rangeland. The predominant vegetation of much of the Northern Great Plains has forever changed; however, our management has not always adapted with these changes. Many times we try to change the rangeland to meet the preferences of the current society (i.e., beef production), instead of readily adapting to the current products of rangeland to meet the needs of the current and future societies (e.g., sustainable food production or clothing production). Very often this preference-driven management comes at a great cost through herbicide, fuel, and equipment purchases that may not be economically or ecologically sound. Other times we are trying to base our management on principles developed from presettlement rangelands (e.g., grazing timing and intensity). Management that is adaptive to the ever changing rangeland products of the Northern Great Plains would seem to be the best approach.

We give two examples of potential management adaptations for leafy spurge and the cool-season grasses Kentucky bluegrass and smooth bromegrass. As stated previously, leafy spurge decreases income from cattle production because of loss of forage; however, little is said concerning the increase in potential forage, and thus income, by grazing goats and sheep on leafy spurge-infested lands. Diversifying management to multiple species grazing, to the multiple resources being provided by rangeland, will increase overall meat production while enhancing the health of the rangeland. Multispecies grazing can be further supported in the Northern Great Plains by noting that the increase in invasive species has been correlated mainly to the decrease in sheep numbers, but also to the increase in cattle numbers, in the western United States. ${ }^{40}$ Grazing smooth bromegrass and Kentucky bluegrass earlier at a higher intensity and reducing grazing pressure during warm-season growing months has been shown to increase plant species diversity and yields while utilizing two high-quality forages currently being produced by Northern Great Plains rangelands. In closing, we know that prairie plant communities historically shifted in composition for a variety of reasons, while the diverse herbivore populations present would respond, with some proliferating and others decreasing due to forage requirements. The question then becomes, why can't our rangeland operations do the same today?

\section{References}

1. Northern Great Plains Floristic Quality Assessment PAnel. 2001. Coefficients of conservatism for the vascular flora of the Dakotas and adjacent grasslands. U.S. Geological Survey, Biological Resources Division. Reston, VA, USA: Information and Technology Report USGS/BRD/ITR-2001-0001. $32 \mathrm{p}$.

2. Samson, F., and F. Knopf. 2004. Prairie conservation in North America. Bioscience 44:418-421.

3. Commission for Environmental Cooperation. 2006. Ecological regions of North America. Map: including ecological region descriptions. Montreal, Quebec, Canada: Commission for Environmental Cooperation.

4. DeKeyser, S., G. Clambey, K. Krabbenhoft, and J. Ostendorf. 2009. Are changes in species composition on central North Dakota rangelands due to non-use management? Rangelands 31:16-19.

5. Grant, T. A., B. Flanders-Wanner, T. L. Shaffer, R. K. Murphy, and G. A. Knutson. 2009. An emerging crisis across northern prairie refuges: prevalence of invasive plants and a plan for adaptive management. Ecological Restoration 27:58-65.

6. Bonos, S. A., And J. A. Murphy. 1999. Growth response and performance of Kentucky bluegrass under summer stress. Crop Science 39:770-774.

7. McKone, M. J. 1985. Reproductive biology of bromegrass. American Journal of Botany 72:1334-1339.

8. Vinton, M. A., And E. M. Goergen. 2006. Plant-soil feedbacks contribute to the persistence of Bromus inermis in tallgrass prairie. Ecosystems 9:967-976.

9. Rogler, G. A., And R. J. Lorenz. 1983. Crested wheatgrass: early history in the United States. Journal of Range Management 36:91-93.

10. Johnson, K. L. 1986. The social values of crested wheatgrass: pros, cons and tradeoffs. In: K. L. Johnson [ED.]. Crested wheatgrass: its values, problems, and myths. Symposium proceedings; 3-7 October 1986; Logan, UT, USA. Logan, UT, USA: Utah State University. p. 331-335. 
11. Christian, J. M., and S. D. Wilson. 1999. Long-term ecosystem impacts of an introduced grass in the northern Great Plains. Ecology 80:2397-2407.

12. Henderson, D. C., and M. A. Naeth. 2005. Multi-scale impacts of crested wheatgrass invasion in mixed-grass prairie. Biological Invasions 7:639-650.

13. Morrow, L. A., and P. W. Stahlman. 1984. The history and distribution of downy brome (Bromus tectorum) in North America. Weed Science 32:2-6.

14. Haferkamp, M. R., and R. K. Heitschmidt. 1999. Japanese brome impacts on western wheatgrass in Northern Great Plains rangelands: an update. Great Plains Research 9:315-327.

15. MAck, R. N. 1981. Invasion of Bromus tectorum L. into western North America: an ecological chronicle. Agro-Ecosystems 7:145165.

16. Ogle, S. M., W. A. Reiners, and K. G. Gerow. 2003. Impacts of exotic annual brome grasses (Bromus spp.) on ecosystem properties of northern mixed grass prairie. American Midland Naturalist 149:46-58.

17. Haferkamp, M. R., R. K. Heitschmidt, and M. G. Karl. 1997. Influence of Japanese brome on western wheatgrass yield. Journal of Range Management 50:44-50.

18. Goodwin, K., R. Sheley, R. Nowierski, and R. Lym. 2003. Leafy spurge: biology, ecology and management. Bozeman, MT, USA: Montana State University, Extension Service Bulletin EB 134. 25 p.

19. Joshi, A., and D. L. Olson. 2009. Revisiting leafy spurge biocontrol: a case study. Rangelands 31:31-35.

20. Leistritz, F. L., D. A. Bangsund, and N. M. Hodur. 2004. Assessing the economic impact of invasive weeds: the case of leafy spurge (Euphorbia esula). Weed Technology 18:1392-1395.

21. Larson, D. L., and J. L. Larson. 2010. Control of one invasive plant species allows exotic grasses to become dominant in northern Great Plains grasslands. Biological Conservation 143:1901-1910.

22. Duncan, C. L. 2001. Knapweed management: another decade of change. In: L. Smith [ED.]. The First International Knapweed Symposium of the Twenty-first Century; 15-16 March 2001; Coeur d'Alene, ID, USA. Albany, CA, USA: USDAAgricultural Reseach Service. p. 1-7.

23. Sheley, R. L., B. E. Olson, and C. Hoopes. 2005. What is so dangerous about the impacts of noxious weeds on Montana's ecology and economy? Bozeman, MT, USA: Montana State University Extension Service Bulletin No. 152. Available at: http://weedawareness.org/impact.html. Accessed 16 September 2010.

24. Tyser, R. W., And C. H. Key. 1988. Spotted knapweed in natural area fescue grasslands: an ecological assessment. Northwest Science 62:151-160.

25. R. G. Sheley, J. S. Jacobs, and M. F. Carpinelli. 1998. Distribution, biology, and management of diffuse (Centaurea diffusa) and spotted knapweed (Centaurea maculosa). Weed Technology 12:353-362.

26. Fuhlendorf, S. D., And D. M. Engle. 2004. Application of the fire: grazing interaction to restore a shifting mosaic on tallgrass prairie. Journal of Applied Ecology 41:604-614.

27. Stacy, M. D., B. L. Perryman, P. D. Stahl, and M. A. Sмiтн. 2005. Brome control and microbial inoculation effects in reclaimed cool-season grasslands. Rangeland Ecology and Management 58:161-166.
28. Hanson, R., T. Christner, S. Clay, D. Clay, S. Smart, And E. Mousel. 2010. Spring burning and rotational grazing effects on cool and warm season grasses in eastern South Dakota. In: D. Child [ed.]. Proceedings of the Society for Range Management 63rd Annual Meeting; 7-11 February 2010; Denver, CO, USA. London, United Kingdom: Oxford Abstracts, Inc. Abstract P C-99.

29. Smart, A., E. Mousel, S. Clay, and D. Clay. 2010. Effects of burning, intensive clipping, and late season nitrogen application in the northern tallgrass prairie. In: D. Child [ed.]. Proceedings of the Society for Range Management 63rd Annual Meeting; 7-11 February 2010; Denver, CO, USA. London, United Kingdom: Oxford Abstracts, Inc. Abstract P C-7.

30. Masters, R. A., K. P. Vogel, and R. B. Mitchell. 1992. Response of Central Plains tallgrass prairies to fire, fertilizer, and atrazine. Journal of Range Management 45:291-295.

31. Dalgleish, H. J., and D. C. Hartnett. 2009. The effects of fire frequency and grazing on tallgrass prairie productivity and plant composition are mediated through bud bank demography. Plant Ecology 210:411-420.

32. Towne, E. G., And K. E. Kemp. 2008. Long-term response patterns of tallgrass prairie to frequent summer burning. Rangeland Ecology \& Management 61:509-520.

33. Anderson, K., And W. McMurphy. 1965. Burning Flint Hills range. Journal of Range Management 18:265-269.

34. Hartnett, D. C., K. R. Hickman, and L. E. Fischer WALKer. 1996. Effects of bison grazing, and topography on floristic diversity in tallgrass prairie. Journal of Range Management 49:413-420.

35. Bangsund, D. A., J. A. Leitch, and F. L. Leistritz. 1996. Economics of herbicide control of leafy spurge (Euphorbia esula L.). Journal of Agricultural and Resource Economics 21:381-395.

36. Hodur, N. M., F. L. Leistritz, and D. A. Bangsund. 2006. Biological control of leafy spurge: utilization and implementation. Rangeland Ecology and Management 59:445-452.

37. Kirby, D. R., T. P. Hanson, and C. H. Sieg. 1997. Angora goats grazing leafy spurge (Euphorbia esula)-infested rangeland. Weed Technology 11:734-738.

38. Launchbaugh, K., and J. Walker. 2006. Targeted grazing: a natural approach to vegetation management and landscape enhancement. Englewood, CO, USA: American Sheep Industry Association. 199 p.

39. North Dakota Department of Agriculture. 2010. State noxious weed acreage survey. Available at: http://www. agdepartment.com/weedsurvey/report.asp. Accessed 29 April 2010.

40. Walker, J. W. 1994. Multi species grazing: the ecological advantage. Sheep Research Journal Special Issue:52-64.

Authors are Rangeland Specialist, Agriculture and Extension Service Animal and Range Sciences, edward.dekeyser@ndsu. edu (DeKeyser), and Graduate Student, Natural Resources Management (Meehan), North Dakota State University, Fargo, ND 58105, USA; Rangeland Management Specialist, North Dakota State University Extension Service, Fargo, ND 58105, USA (Sedivec); and Rangeland Specialist, North Dakota State University Central Grasslands Research Extension Center, Streeter, ND 58483, USA (Lura). 